Шапсугова Мариетта Дамировна

Кандидат юридических наук, доцент, Старший научный сотрудник сектора предпринимательского и корпоративного права Институт государства и права Российской академии наук

\title{
THE STATUS OF AN ENTREPRENEUR FOR SELF-EMPLOYED CITIZENS UNDER THE PROCUREMENT LEGISLATION
}

Аннотация: C принятием поправок в законодательство о закупках статус самозанятых был приравнен к статусу малого и среднего предпринимательства. Подобные изменения в законе кардинальным образом изменили правовой статус самозанятых, ранее не идентифицировавшихся как предпринимателей. Встатье анализируются новые положения Федерального закона от 27 декабря 2019 г. N 474-Ф3 "О внесении изменений в статью 25.1 Федерального закона "О развитии малого и среднего предпринимательства в Российской Федерации" и статью 8 Федерального закона "О закупках товаров, работ, услуг отдельными видами юридических лиц".

Ключевые слова: мальй и средний бизнес, субъекты малого и среднего бизнеса, самозанятые граждане, плательщики налога на профессиональный доход, предприниматели, субъекты предпринимательского права, граждане, физические лица, закупки, юридические лища.

Key words: small and medium-sized businesses, small and medium-sized businesses, selfemployed citizens, payers of professional income tax, entrepreneurs, subjects of business law, citizens, individuals, purchases, legal entities.

The fourth industrial revolution creates conditions for the development of microbusinesses, the smallest units of entrepreneurship. One of the catalysts of this process is the digitalization of the service sector. Thanks to the emergence of digital platforms, small businesses, including single-person companies, and even individuals, both with and without entrepreneurial status, have gained access to a broad market. The latter include the self-employed who have received official status and freelance s not accounted for by official statistics. The 
share of individual self-employed in their total number in the EU countries is very high and in none of them falls below $50 \%$ with an average value of $70 \%[1]$.

So, within the meaning of the current legislation, does the self-employed activity belong to the entrepreneurial one?

According to paragraph 1 of Art. 23 of the Civil Code of the Russian Federation, a citizen has the right to engage in entrepreneurial activity without forming a legal entity from the moment of state registration as an individual entrepreneur, except the cases provided for by paragraph two of this paragraph. Concerning certain entrepreneurial activity types, the Law may provide for the conditions for citizens to carry out such activities without state registration as an individual entrepreneur.

Thus, civil legislation provides for the possibility of carrying out entrepreneurial activities without registering as an entrepreneur.

The uncertainty of the legal status of the self-employed can give rise to practical problems. For example, due to the lack of a self-employed current account, cash receipts in payment for work and services are transferred to their accounts of individuals. According to Federal Law 115, "On Combating Money Laundering and Terrorist Financing," this can lead to blocking accounts of self-employed accounts in the existing banking compliance system. The mass media published messages about massive blocking of self-employed accounts [2]; however, we could not find confirmation of this.

Based on logic, one can assume that clause 3 of Article 23 of the Civil Code of the Russian Federation, which regulates citizens' entrepreneurial activity, applies to self-employed persons. Simultaneously, it is not easy to draw a clear line between self-employment and individual entrepreneurship based on current legislation.

Essentially, the activities of a self-employed citizen hardly differ from the activities of an individual entrepreneur. However, formal legal differences are significant. Summarizing the above, we believe that a self-employed citizen's activity does not imply the use of hired labor and is limited to certain areas of its application. The Law establishes a relatively narrow scope of employment of self-employed citizens, but it is not limited to the types of activities listed in the Law in reality. Also, its focus on meeting personal, domestic, and (or) other similar individuals' needs has legal significance.

Federal Law of December 27, 2019N 474-FZ " On Amendments to Article 25.1 of the Federal Law" On the development of small and medium enterprises in the Russian Federation "and Article 8 of the Federal Law" On procurement of goods, works and services of certain kinds 
of legal persons " with Tatya 8 of the Federal Law of July 18, 2011, № 223-FZ" on procurement of goods, works and services of certain kinds of legal entities " (after this - the Federal Law № 223-FZ) was supplemented part 15. This story circulated n Assumption Federal Law N 223-FZ , concerning the participation of small and medium-sized businesses in the procurement of goods, works, services, are applied during the experiment period established by the Federal Law of November 27, 2018 N 422-FZ "On experimenting with establishing a special tax regime "Tax on professional income" (after this - the Law on tax on professional income), to individuals who are not individual enterprises owners and applying a special tax regime "Tax on professional income".

This provision came into force on March 22, 2020.

By self-employed, we mean payers of professional income tax.

In connection with the Law's changes under consideration, the status of a self-employed person as a taxpayer for professional income tax has been transformed into a small and mediumsized business entity under the Law on the development of small and medium-sized businesses. Before the entry into force of amendments to the procurement legislation, self-employed individuals were considered individuals engaged in a particular economic activity type [3].

According to the Law on the tax on professional income, they include individuals, including individual entrepreneurs, who apply this special tax regime - "tax on professional income."

It should be noted that the Federal Law of April 1, 2020, N 101-FZ "On Amendments to Article 1 of the Federal Law" On Conducting an Experiment to Establish a Special Tax Regime "Professional Income Tax," this tax regime can be introduced in all constituent entities of the Russian Federation based on the laws of the subjects. With the adoption of the Law of the Republic of Ingushetia of August 31, 2020, N 30-RZ, which comes into force from 01.10.2020. such laws have been adopted in all eighty-five constituent entities of Russia.

Up to this point, the part in the procurement of a self-employed person with the application of the legal status of a small and medium-sized business entity could be limited by the territory of the subject-participant of the experiment to establish a special tax regime "tax on professional income" (part 1 of article 2 of the Federal Law on tax on professional income).

Part 3 of Art. 2 of the Law on the Tax on Professional Income provides that a citizen operating in several entities' territory to apply the special tax regime "tax on professional income" chooses the subject in the territory of which he will operate. 
On this basis, in the Letter of the Federal Tax Service of February 21, 2019, N SD-4-3 / $3012 @$ "On the application of a special tax regime" tax professional income " clarified that if the individual provides services in the region of the Russian Federation, included in the experiment, and the constituent entities of the Russian Federation not included in the experiment. When registering as a taxpayer of the NPA, he chose the subject included in the experiment, then, subject to the remaining restrictions provided by the Law, such an individual has the right to apply the NPA about all income, which are the object of taxation of NPD.

Previously, the self-employed could participate in procurement in individuals' status and did not fall under the special legal regime for participation in the procurement of small businesses and businesses under Federal Law N 223-FZ.

Moreover, an entrepreneur's very status has not been extended and does not apply today (except the mentioned above novelty of the legislation on purchases carried out by certain types of legal entities).

In connection with the enactment of the new norm, questions arose on the application of the provisions of the Federal Law of 05.04.2013 N 44-FZ "On the contract system in the field of procurement of goods, works, services to meet state and municipal needs" (after this - Federal Law N 44 -FZ), on preferences for small and medium-sized businesses to self-employed citizens.

The regulator confirms the possibility of participation of self-employed citizens in procurement by Federal Law N 44-FZ. Since according to Part 1 of Art. 2 of the Federal Law on the tax on professional income, this tax regime can be applied by individuals operating in the territory of the subject participating in the experiment to establish a special tax regime "tax on professional income," any individual has the right to take part in the procurement carried out by Federal Law N 44-FZ, including self-employed (Letter of the Ministry of Finance of Russia dated May 27, 2020, N 24-05-07 / 44804).

Thus, under Federal Law No. 44-FZ, self-employed persons participate in procurement on shared grounds with individuals. The provisions of this Law on small and medium-sized businesses do not apply to them.

Ensuring the balance between public and private interests[4], fair competition, and social justice in procurement [5] requires the further elaboration of the self-employed legal status.

The next step on the road to the legitimation of entrepreneurial self-employed status should be amendments to the Federal Law № 44 -FZ and the Federal Law of July 24, 2007 N 209-FZ "On the development of small and medium enterprises in the Russian Federation" (after this - Federal Law on the development of small and medium-sized businesses ). Such changes 
should reflect the attitude of self-employed citizens to small and medium-sized businesses to receive state support and preferences that small and medium-sized businesses have by the legislation on developing small and medium-sized businesses.

\section{References:}

1. Bögenhold D., Klinglmair R., Kandutsch F. (2017) Solo Self-Employment, Human Capital and Hybrid Labor in the Gig Economy. Foresight and STI Governance, vol . 11, no.4, pp . 23-32. P . 26. DOI : 10.17323 / 2500-2597.2017.4.23.32

2. Ershova I.V. Economic activity: concept and relationship with related categories // Lex russica. 2016. N 9 (118). [Electronic resource] ATP "Consultant Plus" (accessed 15.07.2020)

3. Ershova I.V., Trofimova E.V. Self-employment: benchmarks for the formation of a legal regime // Entrepreneurial law. 2017. N 3. S. 3 - 12. [Electronic resource] ATP "Consultant Plus" (date of treatment 15.07.2020)

4. Zankovsky S.S. Public and private principles in the legal regulation of the economy. In the collection: Entrepreneurial Law in the XXI century: continuity and development. Academic Law University at the Institute of State and Law of the Russian Academy of Sciences; MZ Press. Moscow, 2002. Pp. 26-41.

5. Kleandrov M.I. On the need for an unregistered entrepreneur to obtain legal status // Entrepreneurial Law. 2015. N 3.

6. Koshkina Y. Self-employed met with blocking [Electronic resource] https://www.banki.ru/news/daytheme/?id=10891848 (accessed 15.07.2020)

7. E. S. Kryukova, V. D. Ruzanova Individual entrepreneur and self-employed citizen: relationship of concepts // Laws of Russia: experience, analysis, practice. 2018. N 3. Pp 21 - 26.

8. Popkova Zh.G. A new category of self-employed persons: problems of legal status // Law and Economics. 2017. N 2. [Electronic resource] SPS "Consultant plus" (accessed 15.07 $.2020)$

9. Solovyanenko N.I. Development of constitutional principles in the legislation on state and municipal purchases in Russia // Proceedings of the Institute of State and Law of the Russian Academy of Sciences. 2014. N. 1. Pp. 120-128. 